\title{
Acute lymphoblastic leukemia with pregnancy: a rare case
}

\author{
Surbhi Bhargava*, Manju Lal, Manisha Sharma
}

Department of Obstetrics \& Gynaecology, SRHU, Swami Ram Nagar, Doiwala, Dehradun, Uttarakhand, India

Received: 27 March 2015

Accepted: 18 April 2015

\section{*Correspondence:}

Dr. Surbhi Bhargava,

E-mail: surbhibhargava87@gmail.com

Copyright: (C) the author(s), publisher and licensee Medip Academy. This is an open-access article distributed under the terms of the Creative Commons Attribution Non-Commercial License, which permits unrestricted non-commercial use, distribution, and reproduction in any medium, provided the original work is properly cited.

\section{ABSTRACT}

Pregnancy complicated with leukemia is rare. Validated data out of which conclusions may be drawn regarding management of pregnancy with leukemia are sparse.

Keywords: Acute lymphoblastic leukaemia, Pregnancy, Termination

\section{INTRODUCTION}

Acute lymphoblastic leukemia is rare in pregnancy with an estimated incidence of 1 per 75000 to 100000 pregnancies annually with slight male predominance. ${ }^{1}$ In non-pregnant adult patients, treatment results in complete remission in $80 \%$ cases. The basic principle of ALL treatment is combination chemotherapy with sequential administration of induction, consolidation and maintenance therapy and this also holds for ALL in pregnancy. Although the short term risks for children exposed in utero to cytotoxic agents are predictable, there is little information on long term complications. The prognosis in pregnancy is poor and termination of the pregnancy needs to be considered.

\section{CASE REPORT}

A 22 years old female, primigravida came to gynaecology OPD in HIHT with pregnancy of 7 weeks 3 days. She was a known case of acute lymphoblastic leukaemia since 1 year was on treatment since then. She was married for 4 months and conceived while still on cytotoxic drugs-daunorubicin, vincristine, L-aspariginase, methotrexate. Her last menstrual period-13/4/13. Her previous cycles were normal, 3-4 days after 28-30 days with regular flow. She had history of transfusion of 14 units platelets and 2 units packed red cells in the last few months. On examination-her vitals were stable. On per abdomen examination, abdomen was soft. Per vaginum examination revealed pin point os, uterus of 6 weeks size, $\mathrm{b} / 1$ fornices free. Her investigations: $\mathrm{Hb}-11.5 \mathrm{gm} / \mathrm{dl}$, TLC - 6090/cumm, platelet - 136000, PT - 14.7, INR - 1.11, $\mathrm{HIV}$ and HBsAg - non reactive. Patient was explained about the teratogenic effect of the cytotoxic drugs and was offered for termination and high risk consent was taken from husband for medical termination of pregnancy. Patient was then admitted for suction and evacuation which was done under sedation. The post procedure period was uneventful.

\section{DISCUSSION}

The occurrence of leukemia during pregnancy is very rare. It has been estimated that during pregnancy most leukemias are acute: two thirds are acute myeloid leukemia (AML) and one third are acute lymphoblastic leukemia (ALL). Acute leukemia is invariably fatal and without aggressive treatment with cytotoxic drugs, the disease is characterized by rapid deterioration and death within weeks of diagnosis. AL can affect pregnancy and the fetus, clinical problems result from the disease process itself and its treatment. Intrauterine growth retardation, pre-term labor and spontaneous abortions and 
still births are common in $\mathrm{AL}$ without treatment. Fetal loss occurs in approximately $33 \%$ of women with AL. ${ }^{2}$ With supportive therapy alone $20-30 \%$ of women did not survive the gestation period and fetal mortality was $50 \%$. $^{3}$ Pregnant leukemic women should be treated as nonpregnant women with aggressive chemotherapy until the remission is achieved. The risk of malformations in first trimester is as high as $17 \%$ especially with folate antagonists. ${ }^{4}$ Therapeutic abortions should be considered in early gestation, but if the woman decides to continue her pregnancy, chemotherapy should be started and certain drugs like methotrexate should be replaced. Standard anti leukaemic treatment can be given in second and third trimester if appropriate monitoring and obstetric care are available. Delivery should be accomplished when fetal survival can be ensured and the mother is in complete remission. In first trimester a teratogenic effect of the chemotherapeutic agents used for the treatment of leukemia can occur. ${ }^{5}$ A diltation and curettage is usually considered the first option, but to terminate pregnancies of upto 63 days of amenorrhoea, and increasingly at all gestations, the antiprogesterone mifepristone in combination with a prostaglandin analogue(misoprostol) provides a suitable non-surgical method. ${ }^{6}$ In patients in the middle of chemotherapy with a very low platelet count, a spontaneous abortion might result in profuse bleeding. Platelets are given if their numbers fall to less than $10000 / \mu 1$. Acute leukaemia thus requires immediate treatment, irrespective of gestational age. Termination of pregnancy and the risks of chemotherapy need to be discussed with the patient. More studies are required to establish the prognosis of ALL with pregnancy, but this is difficult due to low prevalence.

Funding: No funding sources

Conflict of interest: None declared

Ethical approval: Not required

\section{REFERENCES}

1. Lichtman M, Liesveld J. Acute myelogenous leukemia. In: Beutler E, Lichtman M, Coller B, eds. Williams Hematology 6th ed. New York, NY: McGraw-Hill; 2001: 1047-1084.

2. Mclain CR. Leukemia in pregnancy. Clin Obstet Gynecol. 1974; 17:185-94.

3. Dhubhashini, Raghuram G. Pregnancy complicated by malignancy. In: Krishna U, Daftary S, eds. Pregnancy at Risk: Current concepts. 1st ed. New Delhi: FOGSI Publication, Jaypee Brothers; 1997: 255-259.

4. Brell J, Kalajcio M. Leukemia in Pregnancy. Semin Oncol. 2000;27:667-77.

5. Schaefer C. Drugs during pregnancy and lactation. In: Schaefer C, eds. A Book. 1st ed. US: Elseveir science; 2001.

6. Ashok PW, Flett GW, Templeton A. Termination of pregnancy at 9-13 weeks amenorrhea with mifepristone and misoprostol. Lancet. 1998;352:542-3.

DOI: $10.18203 / 2320-1770$. ijrcog20150120

Cite this article as: Bhargava S, Lal M, Sharma M. Acute lymphoblastic leukemia with pregnancy: a rare case. Int J Reprod Contracept Obstet Gynecol 2015;4:887-8. 